\title{
The influence of landscape structure on the quality index of surface waters
}

\author{
Tetyana P. FEDONIUK ${ }^{1) B C D} \bowtie$, Roman H. FEDONIUK ${ }^{2) \text { BEF, }}$ \\ Ludmila D. ROMANCHUK ${ }^{3)}$ AD , Anatolyy A. PETRUK ${ }^{4) ~ B E F, ~}$ \\ Viktor M. PAZYCH ${ }^{\text {) BE }}$
}

1) orcid.org/0000-0002-6504-0893; Zhytomyr National Agroecological University, Staryi Blvd, 7, Zhytomyr, Zhytomyrs'ka oblast, 10002 Ukraine; e-mail: tanyavasiluk2015@gmail.com

2) orcid.org/0000-0001-8473-1772; Zhytomyr National Agroecological University, Ukraine; e-mail: rfedonyk@gmail.com

3) orcid.org/0000-0003-4790-8414; Zhytomyr National Agroecological University, Ukraine; e-mail: ludmilaromanchuck14@gmail.com

4) orcid.org/0000-0002-7947-5740; State Ecological Inspection in Rivne Region, Rivne, Ukraine; paa7@meta.ua

${ }^{5)}$ orcid.org/0000-0002-1597-2334; Zhytomyr National Agroecological University, Ukraine; e-mail: forest.znau@ukr.net

For citation: Fedoniuk T.P., Fedoniuk R.H., Romanchuk L.D., Petruk A.A., Pazych V.M. 2019. The influence of landscape structure on the quality index of surface waters. Journal of Water and Land Development. No. 43 (X-XII) p. 56-63. DOI: 10.2478/jwld-2019-0063.

\begin{abstract}
The article focuses on the problem of structure degradation and ecosystem functioning - the urgency that identifies the relevance of operations at a strategic level aimed at providing the integrated assessment of ecological stability of water. Determination of water quality indicators were divided into blocks according to the criteria of salt composition, according to chemical saprobological indicators and the content of specific substances of toxic and radiation action. According to the results of block analysis, the integrated ecological index of water quality was determined by the dependence of water quality on the indicators of ecological stabilization of the landscape and the structure of biotechnical elements. The article determines the relationships between worsening quality of surface waters and stabilization or destabilization of the landscape structure. The research was conducted on medium and large streamflows on the Right Bank of Polesie region of the Dnieper-River cascade within which the tracts of land were identified and the landscape ecological stability (CESL1) and landscape biotechnical elements coefficients (CESL2) were determined. The retrospective analysis was performed of the surface water features on the Right Bank of Polesie region of the Dnieper- River cascade and the main trends in salt block indicators, trophic and saprobiological block indicators, and in the content of toxic and radioactive substances at observation sites were estimated. Based on obtained data, the integrated assessment in trends of surface water quality on the Right Bank of Polesie region of the Dnieper- River cascade was made and the main parameters and scale of stabilization and destabilization of landscape impact on the water quality formation were defined.
\end{abstract}

Key words: degradation, landscape stability, surface water, the Dnieper-River cascade, water quality

\section{INTRODUCTION}

Many integrated approaches to the assessment of the basins structure impact on water quality recognize the interdependence between resources and components and are of vital importance for supporting long-term management of natural resources [ZHOU et al. 2012]. The landscape structure of the territories is the key parameter of water quality formation, as water quality depends on landscape ability to retain and purify water [DOSSKEY et al. 2010]. In the recent years more attention has been paid to the role of coastal buffer systems for filtration of sediments, nutrients 
and pesticides from agricultural lands on coastal areas [URIARTE et al. 2011]. It is proved that the largest proportion (more than $80 \%$ ) of pollution comes to the reservoirs with surface streams [MIODUSZEWSKI 2015]. The scientists note that a number of terrestrial elements, in particular coastal forests, agricultural areas, industrial facilities, play an important part in the determination of surface water quality; they may markedly change a broad range of physical and chemical parameters of surface water. Therefore, the approach of basin structure determination was always taken in consideration [MIATKOWSKI, SMARZYŃSKA 2017; RAMDANI, LAIFA 2017; UUEMAA et al. 2007]. Some studies indicate a special role of grasslands as a stabilizing component of landscapes that affects the formation of surface water quality [JANKOWSKA-HUFLEJT 2006]. It is obvious that the research of landscape structure impact on surface water covers small size areas and is widely used in many countries [AMIRI, NAKANE 2009; LEE et al. 2009; NASH et al. 2009; SHEN et al. 2015].

In the recent decades, the basin of the Dnieper-River cascade has been considered with regard to the maximum development of basin surface for agricultural production, including streams for sewage disposal, irrigation etc., and the quality of surface water has been estimated from the perspective of consumerism [DUBNIAK, DUBNIAK 2012]. The effect of this mass consumerism on the environment is a sizeable overload of natural buffering capacity of water, worsening self-purification capacity and ecological crisis phenomena - degradation of fauna and flora, low quality of drinking water and neglect of it as a habitat.

The scientists worldwide use various approaches to the assessment of the landscape impact on water quality. For instance, the authors connect the landscape pattern with qualitative indicators of water (China, Lake Tai) [ZHANG et al. 2010]. In our previous works, we connected structural features of landscapes with species diversity and morphogenetic indicators of macrophytes [FEDONIUK 2018; ROMANCHUK et al. 2018]. Many authors combined the elements of hydrological modelling and remote sensing, landscape ecological analysis and GIS in order to develop the series of indicators for water protection within geographic audit of ecological health and change on a regional scale [ROMANCHUCK et al. 2017; VASENKO et al. 2017]. The research of ecological state of surface water of the Dnieper-River basin was conducted by a group of authors who proved that complex transboundary analysis and strategic planning of measures for the Dnieper-River basin would be impossible without application of the integrated approach and diverse methodology to assess its ecological state. This became the premise for joint research concentrated in transboundary areas in Byelorussia, Russia, Ukraine with the support of a number of international organizations [GRODZINSKY et al. 2005; VASENKO 2005; VASENKO et al. 2016]. Thus, the assessment of analysed landscape stability is an important aspect in the assessment of stability of water bodies' development on these territories. For this purpose, we determined the landscape ecological stability coefficients (CESL), which are the ratio between stabilizing ones (forest areas, natural feeding grounds) and destabilizing (all others).
The research was designed to determine the main factors of the anthropogenic changes of water ecosystems of the ecological corridors in the right-bank wooded part of the Dnieper-River cascade, to estimate the main directions of the dynamics based on the content indices of specific toxic and radioactive substances, to determine the main parameters of the impact of landscapes'stabilization and destabilization on the formation of ecological water quality, to determine the structural and functional characteristics of species diversity within the biggest river-borne ecological corridors of the right-bank wooded part of the DnieperRiver cascade on the areas with different reclamation rate of a river valley landscape.

\section{MATERIALS AND METHODS}

The study was carried out in 2011-2016 in 78 sites within the wooded part of ecological corridors of the Dnieper-River cascade. From among different types of water basins the following rivers were chosen - the Teteriv, the Pripet River and their tributaries - the Gnylopiat, the Irsha, the Guiva, the Zdvyzh, the Ustia, as well as rather big water reservoirs - Chudniv, Vidsichne, Zhytomyr, Irshansk, Malyn.

The research scheme included two blocks. The structural territory characteristics of the typical river ecosystems of the ecological corridors of the Dnieper-River cascade were analyzed in the first block. The chemical and physical data over the period 2011-2016 obtained partly from stationary monitoring stations of the State Water Resources Agency of Ukraine (Ukr. Derzhavne ahentstvo vodnykh resursiv Ukrayiny) and partly by us were used in this study.

According to ROMANENKO, ZHUKINSKIY [1998], all analysis were divided into three blocks: the estimation of water quality based on salt content, on chemical indices and on the content of specific toxic and radioactive substances. The unit for assessing the quality of water according to the criteria of salt content (index $I s$ ) included mineralization, electrolytical conductivity and the concentration of sulfates and chlorides. For each indicator, an individual quality index was determined and the average block index of Is was calculated, taking into account all of these indicators. The unit based on chemical and saprobiological criteria (index Its) included the oxygen regime, suspended matter, transparency, $\mathrm{pH}$, concentrations of ammonium nitrogen, nitrates and nitrites, phosphate-phosphorus, permanganate oxidation, BOD and Coli index. For each indicator, the individual quality index was determined and the average block index of content of specific substances of toxic and radiation - It was calculated, taking into account all of these indicators. The unit for assessing the quality of water based on specific toxic and radioactive substances (index It) included the content of total iron, manganese, copper, petroleum products, phenols, synthetic surfactants in water and cadmium, zinc, chromium and nickel in bottom sediments. For each indicator, the individual quality index was determined and the average block index It was calculated, taking into account all of these indicators.

According to the obtained data, the total ecological water index (Ie) was determined as a mean value of three 
block indices [RomANENKO, ZHUKINSKIY 1998]. To determine the subcategories of water quality corresponding to the average of group and block indices, the water was evaluated in accordance with Table 1 and classified to the categories: 1 - excellent, 2 - very good, 3 - good, 4 - satisfactory, 5 - marginally acceptable, 6 - bad, 7 - very bad.

Table 1. Ranking of block and integrated water quality indices by relevant categories

\begin{tabular}{|c|c|l|}
\hline Index value & $\begin{array}{c}\text { Subcategory } \\
\text { notation }\end{array}$ & \multicolumn{1}{|c|}{ Subcategory name } \\
\hline $1.0-1.2$ & 1 & first \\
\hline $1.3-1.4$ & $1(2)$ & first with a transition to the second \\
\hline $1.5-1.6$ & $1-2$ & between the first and the second one \\
\hline $1.7-1.8$ & $2(1)$ & second with a transition to the first \\
\hline $1.9-2.2$ & 2 & second \\
\hline \multicolumn{3}{|l}{} \\
\hline $6.5-6.6$ & $6-7$ & between the sixth and the seventh one \\
\hline $6.7-6.8$ & $7(6)$ & seventh with a transition to the sixth one \\
\hline $6.9-7.0$ & 7 & seventh \\
\hline
\end{tabular}

Source: own elaboration.

At 20 sites, which carried the highest anthropogenic load, the samples of riverside soil and bed silt were additionally collected.

To estimate the ecological landscape state within the study sites, the methods of E. Klementova and V. Heinihe were used, by which the coefficient of ecological landscape's stabilization (CESL1) and the coefficient of ecological stabilization of biotechnical elements as well as of entire landscape (CESL2) were determined [KLEMENTOVA, HeINIGE 1995]. Determining the CESL1 consisted in mapping the areas occupied by stabilizing and destabilizing elements of the landscape using Equation (1):

$$
C E S L_{1}=\frac{\sum_{i=1}^{n} F_{s t i}}{\sum_{j=1}^{n} F_{n s t} j}
$$

Where: $F_{s t i}=$ areas under crops and plant communities that have a positive effect on the landscape (forests, green plantations, natural meadows, reserves, arable lands used for

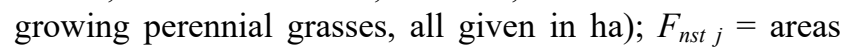
occupied by unstable elements of the landscape (annual cultivated arable land, unstable grasslands, built-up areas and road network, overgrown and muddy reservoirs and other lands that exert anthropogenic impact, all given in ha). CESL1 was assessed on a scale as in Table 2.

The coefficient of ecological stabilization of biotechnical elements and the entire landscape (CESL2) was calculated with Equation (2):

$$
C E S L_{2}=\sum_{i=1}^{n} \frac{f \cdot \mathrm{Ke} \cdot \mathrm{Kgm}}{\mathrm{Ft}}
$$

Where: $f=$ the area of the biotechnical element; $K=$ coefficient characterizing ecological value of separate biotechnical elements; $K g m$ = coefficient of geological-morphological stability of the terrain; $F t=$ the area of the whole territory. CESL2 was evaluated on a scale as in Table 2.

The primary data analysis and their statistical processing were made with Microsoft Excel 2010 and Statistica 12.0 software.
Table 2. The landscape resilience scale according to the values of CESL1 and CESL2

\begin{tabular}{|l|c|c|c|c|}
\hline \multirow{2}{*}{ Landscape characteristics } & CESL1 & & CESL2 & \\
\cline { 2 - 5 } & value & point & value & point \\
\hline Unstable, with a vivid instability & $\leq 0.5$ & 1 & - & - \\
\hline Unstable & $0.51-1.0$ & 2 & $\leq 0.33$ & 1 \\
\hline Conditionally stable & $1.01-3.0$ & 3 & $0.34-0.5$ & 2 \\
\hline Stable & $3.01-4.5$ & 4 & $0.51-0.66$ & $3-4$ \\
\hline Stable, with a vivid stability & $4.5-5.0$ & 5 & $\geq 0.66$ & 5 \\
\hline
\end{tabular}

Source: own study.

\section{RESULTS OF SURFACE WATERS QUALITY}

The ecological corridors of the right-bank part of the Dnieper-River cascade are the territories with diverse anthropogenic load on all components of water ecosystems. The fraction of tilled areas in their basins makes nearly $80 \%$ of the total area of agricultural lands while grasslands and hayfields occupy $16 \%$. Forests occupy $20 \%$ of the total area, which proves the assumption concerning the intensive anthropogenic impact on the water ecosystems of this territory. The intensive economic development of watershed of the rivers under study causes significant anthropogenic impact on aquatic ecosystems, whose state is determined by the delivery of raw waste waters and insufficiently treated sewage waters. A significant tillage of the territory as well as a great number of human settlements has stipulated a high percentage of non-stable landscapes within the territory under study. Therefore, $67.8 \%$ of the landscapes of the right-bank part of the Dnieper-River cascade ecological corridors were characterized by destabilization indicators below 1.0 and defined as "unstable" and nearly $34.9 \%$ demonstrated pronounced signs of destabilization. The highest frequency of occurrence $(21.8 \%)$ in this territory was found for landscapes with CESL1 indicators from 0.4 to 0.6 . On the other hand, $32.2 \%$ of the analysed sites were characterized as stable. Among them, the largest part were objects with CESL1 indicators from 1.4 to 1.6, characterising "relatively stable" landscapes.

Similar calculations were carried out in accordance with the methodology for assessing the landscape by calculating the coefficient of ecological stabilization of biotechnical elements of the landscape (CESL2). The largest part of the study objects was conditionally stable $(57.8 \%)$ and unstable $(25.2 \%)$ landscapes. Moreover, the largest part of sites belonged to the range of CESL2 indicators $=0.3-0.4$, that is, the "transitional category" from "low stable" to "unstable", which also confirms the need for strengthening the stabilizing component within the ecological corridors of the right-bank part of the Dnieper-River cascade. Significant anthropogenic impact on the territory of ecological corridors of the Dnieper-River cascade is exerted by a dense network of settlements, the effect of which manifests itself in the form of dumping of insufficiently treated sewage.

The hydrochemical regime of the rivers under study in almost all areas significantly deteriorated under the influence of anthropogenic factors. This is due to the input of domestic and industrial wastewater in areas downstream the large settlements. This particularly affects the amount of ions like e.g. chlorides and sulphates [SNIZHKO 2002]. 
In summer, the concentration of mineral substances fluctuated from 269 to $322 \mathrm{mg} \cdot \mathrm{dm}^{-3}$. In spring, this indicator declined. Higher indicators of mineral composition are connected, first of all, with the inflow of groundwaters to rivers during this period [SNIZHKO 2002]. According to the ecological classification of surface waters, the extreme indicators of the content of main ions in surface waters of the ecological corridors on the right-bank part of the Dnieper-River cascade did not exceed class 2 .

In the middle of the last century, within this territory, the surface waters contained a meager amount of chlorides (from 3 to $32 \mathrm{mg} \cdot \mathrm{dm}^{-3}$ ) and sulphates (from 6 to 41 $\mathrm{mg} \cdot \mathrm{dm}^{-3}$ ). Thus, the values varied from category 1 (excellent) to category 3 (good) of water quality as assessed by chlorides and did not exceed the permissible indicators for category 1 (excellent) of water quality by the content of sulfates. The concentration of chlorides in water in the period from 1995 to 2015 varied from 27.5 to $76.3 \mathrm{mg} \cdot \mathrm{dm}^{-3}$ in 1995 and from 32.3 to 79.5 in 2005 . At the same time, the average indicators were 38.21 and $55.83 \mathrm{mg} \cdot \mathrm{dm}^{-3}$, respectively. These indicators are typical for categories $1-4$ of environmental classification of water quality.

The analysis of the block of salt index showed that in general, in the retrospective studied periods, it can be characterized as categories 1-2. The maximum indicators of the index in the surface waters of the ecological corridors of the right-bank part of the Dnieper-River cascade may be classified to categories 3-4. The natural state of the river is characterized by the indicators for sulphates $=1$, and for chlorides $=3$, which corresponds to the ecological classification as categories $2-3$.

The data obtained in 2011-2016 confirmed the positive trend in this block of indicators, the value of the generalized block index $I c$ was 2.36, which in general was considered a transitional category 2 (very good) to 3 (good) of class II of water quality.

The distribution of salinity indicators in relation to the degree of ecological stabilization of landscapes showed a general tendency of increasing salt content indicators in response to a decrease in the indicators CESL1, that is, an increase proportional to destabilizing components in the respective landscapes $(r=-0.5089)$ - Figure 1a.

About $20 \%$ of points in Figure 2 represented the objects of salt indices $(I s)$ between 1.5 and 2.0; the ratio of unstable to stable objects in this category was $4: 8$. When deterioration of water quality reached $I s=2.0-2.5$, the share of unstable objects somewhat increased to $6: 8$. Values of $I s$ from 2.5 to 3.0 , that accounted for $27 \%$ of study objects, were stipulated by the proportion of unstable to stable objects as 13:1. Performed analyses testify that the stability level of objects is a strong factor of water quality formation. Therefore, the destabilization of landscape structure causes the deterioration of water quality to $2.5-3.0$ or more.

Approximately the same data were obtained while analysing the landscape structure at the study sites according to CESL2 indices $(r=-0.2675$, Figure $1 b)$. Fifty eight percent of sites with salt indices lower than category 2 were formed under the conditions of unstable and poorly stable objects and the worst-case indicator values of salt concentration corresponded to plots with CESL2 index of 0.2-0.3. a)
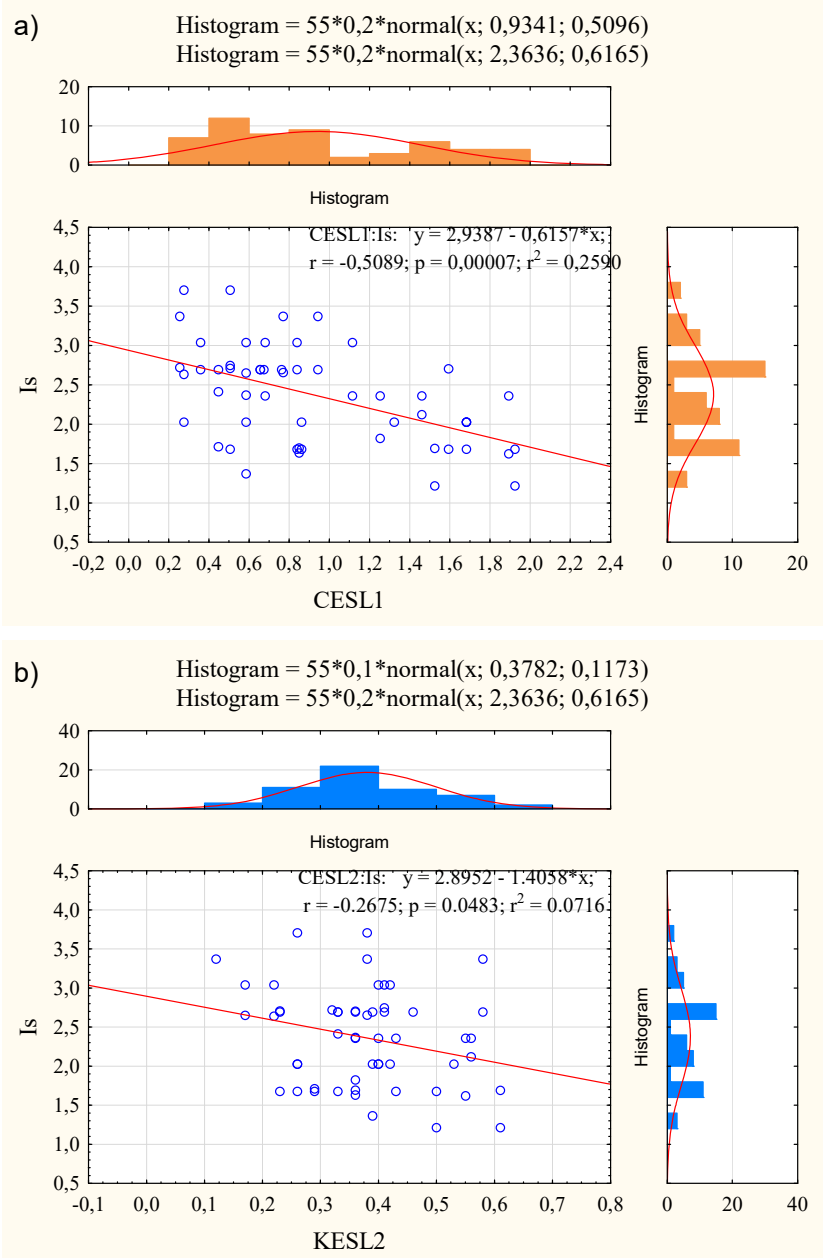

Fig. 1. The distribution of salinity indicators of water in relation to: a) the coefficient of ecological landscape's stabilization (CESL1), b) the coefficient of ecological stabilization of biotechnical elements (CESL2); source: own study

Thus, the landscapes' non-stability affects the salt content in water, but the indicator values of salt content as a rule did not exceed the bounds of category 3 ("good"), and only the worst indices (Is) for water reservoirs of the Dnieper-River cascade in Polesie region approximated water quality to the state that can be characterized as transitional category to "polluted" one.

At the same time, the peculiarities of aquatic ecosystems of the right bank of the Dnieper-River cascade stipulate naturally different correspondence of some saprobiological indices to categories of water quality indices. These differences occurred while examining water transparency, referring it to category $6-7$. The range of $\mathrm{pH}$ variability indicated categories from 1 to 6 , which resulted from mutual effect of anthropogenic and natural factors. According to the average value of block index, the surface water of right bank Polesie part of the Dnieper-River cascade should be related to category 4 - "slightly polluted" water, that shifts to category 5. Some differences in evaluation of trophic and saprobiological status of water were probably connected with the regional peculiarity of water quality formation. The nearest values and the average annual value of block index were observed in biological indices, which 
integrally characterize the development stability level of water bodies; saprobiological indices were typical for the natural water condition and corresponded to category 3 "clean enough" with a shift to category 4 "slightly polluted" that allows to classify them as $\beta^{\prime}$-mesosaprobic and mezoeutrophic waters.

The distribution of indicators of trophic and saprobiological contamination in relation to the degree of ecological landscape stabilization showed a general tendency to the aggravation of the above-mentioned indicator with an increase in the proportion of destabilizing components in the landscape (Fig. 2). This was confirmed by the inverse correlation between Its and CESL1 $(r=-0.4530)$ and CESL2 $(r=-0.3779)$.

Almost half of the objects $(49 \%)$ at the observation sites were characterized by Its in the range of categories $3-$ 4. However, $90 \%$ of the sites with trophic and saprobiological indices below category 4 were formed in conditions of unstable objects, which can indicate that the formation of class III of water quality occurred under the influence of landscape anthropogenic disturbance (Fig. 3a).

Similar data were obtained by calculating CESL2. In particular, $78 \%$ of the sites with water quality indices in

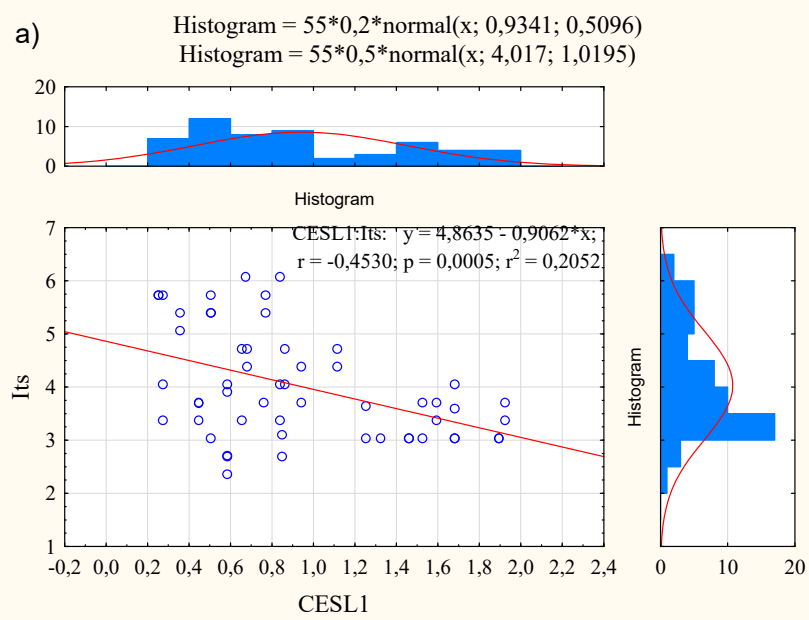

b) Histogram $=55^{*} 0,1 * \operatorname{normal}(\mathrm{x} ; 0,3782 ; 0,1173)$
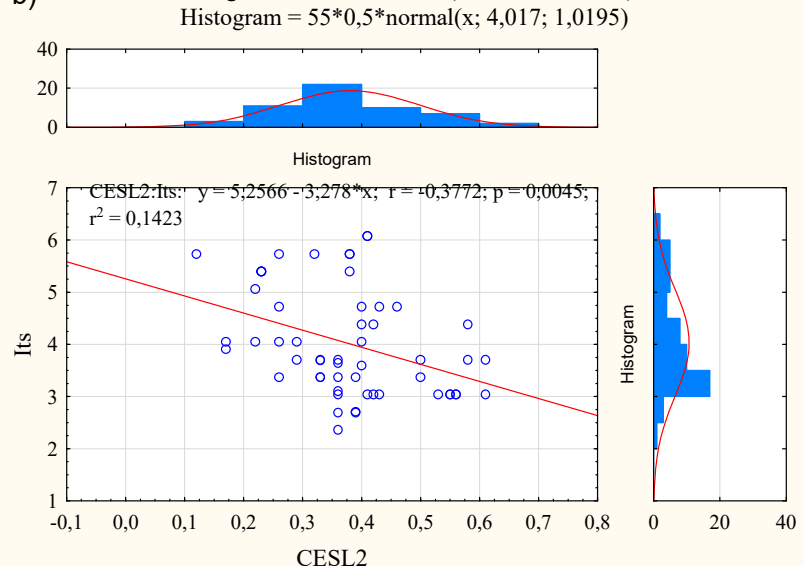

Fig. 2. Distribution of saprobiological indicators of water: a) the coefficient of ecological landscape's stabilization (CESL1),

b) the coefficient of ecological stabilization of biotechnical elements (CESL2); source: own study accordance with the tropho-saprobiological index were formed under conditions of sensitive and unstable landscapes. Almost $80 \%$ of the objects with the Its below category 4 were formed at sites with CESL2 below 0.4 (Fig. 3b). Such data indicate that water quality as assessed by trophic and saprobiological indicators is influenced not only by the ratio of stabilizing and destabilizing objects, but also by the ecological nature of individual biotechnical elements within the landscapes.

Surface waters of the Dnieper-River cascade on the territory of Polesie (Ukr. Polissia or Polisia) region are characterized by the high content of specific toxic substances. The respective block index averaged over the period 1995-2016 ranged from 3.8 to 4.0 with the extreme values between 4.9 and 5.3. In 1995, the mean annual index of the given block equalled 3 , and downstream the majority of settlements it was 3.3-3.6. In the year 2015, this figure varied in the range of 4.0 and 4.9. Some years were not characterized by significant differences in the index values, which may indicate the intense self-purification of aquatic ecosystems by vegetation and the removal of a series of toxic compounds.

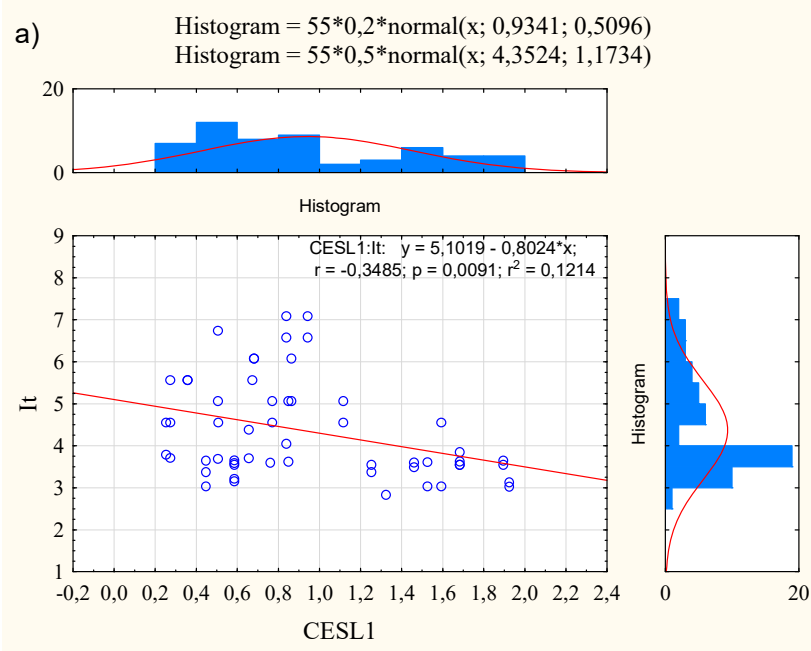

b) $\quad$ Histogram $=55^{*} 0,1 * \operatorname{normal}(\mathrm{x} ; 0,3782 ; 0,1173)$
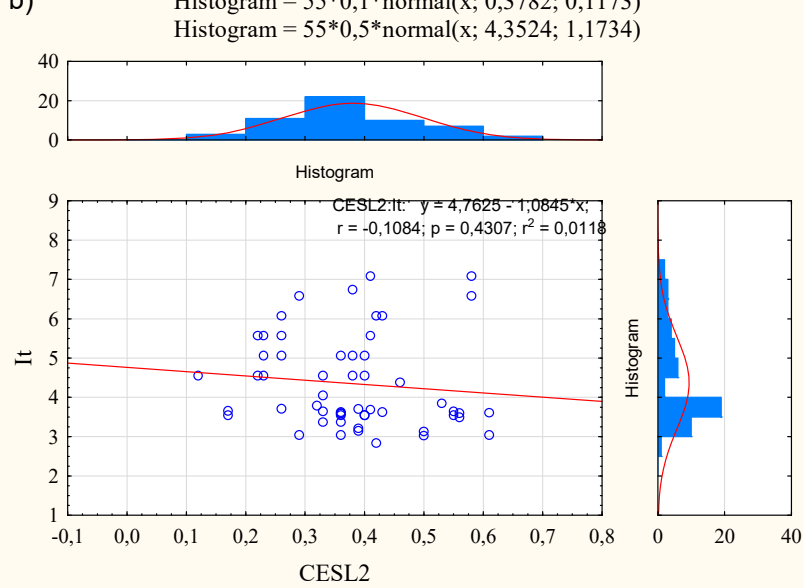

Fig. 3. Distribution of indices based on concentrations of specific toxic substances in water in relation to: a) the coefficient of ecological landscape's stabilization (CESL1), b) the coefficient of ecological stabilization of biotechnical elements (CESL2); source: own study 
Concentrations of phenols in surface waters of the right bank part of the Dnieper-River cascade on the territory of Polesie region can in most cases be attributed to category 2-4 of class III ("slightly contaminated"). Judging by the maximum concentrations, they can be attributed to category 5 ("moderately contaminated"). The average concentrations of synthetic surfactants during this period conformed to categories 4-5 and the maximum concentration - to category 6 ("contaminated").

During the period 1995-2016, petroleum products in surface waters of the right bank part of the Dnieper-River cascade were present in quite diverse concentrations which ranged from 0.0 to $120.0 \mu \mathrm{g} \cdot \mathrm{dm}^{-3}$ in the mid 1990 's, and from 0 to $40 \mu \mathrm{g} \cdot \mathrm{dm}^{-3}-$ in the mid-2000's. According to the environmental classification of water quality, these waters can be classified to category 1 by the best values and to category 5 by the worst ones. The average concentration for the study period was $12.0-13.0 \mu \mathrm{g} \cdot \mathrm{dm}^{-3}$ (category 2 ).

Based on the concentration of copper, analysed surface waters were characterized as "slightly contaminated" and belonged to category 4 . The concentrations varied from 0.0 to $26.0 \mu \mathrm{g} \cdot \mathrm{dm}^{-3}$ (from "very clean" - category 1 to "contaminated" and "bad" - category 6).

A separate point should be noted the increased concentrations of the iron in the surface waters of the right-bank part of the Dnieper-River cascade within the Ukrainian Polesie, where the values are overstated due to geochemical processes, because it is there that the ground waters with the highest concentration of iron ions in the Ukrainian Polesie are discharged there. Thus, in 1984, its performance varied in the range from 20 to $280 \mu \mathrm{g} \cdot \mathrm{dm}^{-3}(1-4$ categories - from "very clean" to "slightly polluted") with an average annual value of $145 \mu \mathrm{g} \cdot \mathrm{dm}^{-3}$ (category 4 ), in 2004 - from 42 up to $1003 \mu \mathrm{g} \cdot \mathrm{dm}^{-3}$ (1-6 categories - from "very clean" to "dirty") with an average annual value of 194.1 $\mu \mathrm{g} \cdot \mathrm{dm}^{-3}$ (4 categories). The iron concentrations in analysed waters varied over the past 20 years from 170 to $720 \mu \mathrm{g} \cdot \mathrm{dm}^{-3}$, that is within water quality categories 4-5. Clear pattern in their seasonal distribution was not identified. Such significant variations in iron concentrations are associated with the geological and biochemical processes of the examined area and with its recharge with ground waters containing higher concentrations of iron.

The concentration of manganese appeared to be high in some years of monitoring. In particular, the tendency of increasing its content in analysed waters was observed during the study period. In 1984 its concentrations varied from 3.0 to $96.0 \mu \mathrm{g} \cdot \mathrm{dm}^{-3}$ (categories $1-4$ from "very clean" to "slightly contaminated") with the mean annual concentration of $10.79 \mu \mathrm{g} \cdot \mathrm{dm}^{-3}$ (category 2). In 2004 - the range was from 2.0 to $207.0 \mu \mathrm{g} \cdot \mathrm{dm}^{-3}$ (categories 1-5 from "very clean" to "moderately contaminated") and the annual mean - $43.3 \mu \mathrm{g} \cdot \mathrm{dm}^{-3}$ (category 3 ). Respective figures for the year 2016 were - from 2.0 to $460.0 \mu \mathrm{g} \cdot \mathrm{dm}^{-3}$ (categories $1-$ 5 from "very clean" to "moderately contaminated") and $57.4 \mu \mathrm{g} \cdot \mathrm{dm}^{-3}$ (category 4 ).

Consequently, it should be noted that contamination by the majority of the listed toxic substances was considered to be at the average level. In most cases the contamination did not exceed the permissible concentrations characteris- tic for category 4 ("slightly contaminated"). Regarding the extreme concentrations, quite often they reached the level of category 6 ("bad" and "contaminated"). It was caused mainly by the influence of anthropogenic activities within definite sites. The increased concentrations of iron, due to the geochemical processes, as well as its high concentration in ground waters can be viewed as an exception.

The degree of stabilization and destabilization of the landscape (CESL1 and CESL2) significantly affected the content of specific toxic and radioactive substances. The supply of these substances is determined by the location of industrial enterprises, the flow of wastewater from settlements, etc., which are considered to be the destabilizing components of landscapes. The majority of objects within the right bank part of the Dnieper-River cascade on the territory of Polesie region were characterized by an increased contamination with toxic substances. Fifty three percent of sites corresponded to categories 3-4, from 5 to $15 \%$ corresponded to category 4 and all the others were classified below category 5 . Almost $40 \%$ of all sites in the category of unstable, instable and medium-stable landscapes were characterized by indices of specific toxic and radioactive substances below category 3 , and about $15 \%$ below category 4 . Generally negative effect of landscape destabilization on indices of the toxic substances was confirmed by the inverse correlation $(r=-0.348)$ shown in Figure 3a.

Therefore, our analyses demonstrate that destabilization of landscapes and their transition to the category of "unstable" caused water deterioration reflected by It switching from categories 3-4 ("clean enough" - "slightly contaminated") to categories 3-7 ("clean enough" - "highly contaminated").

It should be noted that significant relationships between the coefficient of ecological stabilization of biotechnical landscape elements (CESL2) and the quality of water assessed from the concentrations of toxic and radioactive substances were not revealed. Forty percent of the studied sites were situated in landscapes with values of CESL = $0.3 . .0 .4$, among which the majority of water samples were classified to categories 3-5 (Fig. 4b). However, the overwhelming majority of sites with the values of It below category 5 were formed within the limits of instability and unstable landscapes. Therefore, it can be assumed that the formation of water quality of $I t$ index below category 5 was related to the level of ecological destabilization of biotechnical elements. However, due to low statistical reliability, this conclusion requires further in-depth study.

\section{CONCLUSIONS}

It was established that the territory of ecological corridors of the right-bank Polesie part of the Dnieper-River cascade is an area of rather modest intensity of anthropogenic impact on all components of aquatic ecosystems. The analysis of the dynamics of salt concentrations in water suggests that, generally, the average indexes of water can be characterized as categories $1-2$, at maximum - as categories 3-4. In the block of trophic and saprobiological indicators, certain features were noted. The first is the low 
transparency of water throughout the river, due to abundant vegetation of the bank strip and the input of significant amounts of humic substances. Another reason is the composition of groundwater that feeds the main watercourses of the right-bank part of the Dnieper-River cascade. Groundwaters are characterized by a high concentration of iron in almost all investigated sites. Significant areas of the river floodplain are marshy and overpopulated, which is manifested by the increased levels of BOD and permanganate oxidation due to the input of humic substances. Increased levels of organic compounds are also due to the flow of sewage and surface waters from terrestrial areas. Surface waters of the right bank part of the Dnieper-River cascade are characterized by high content of specific toxic substances. The value of the index of specific indicators increases in the areas adjacent to settlements.

Sixty six percent of the studied landscapes were characterized by the values of CESL1 below 1.0 and classified as "unstable", $35 \%$ of which with pronounced signs of destabilization. Destabilization of the landscape structure causes deterioration of the quality of water to category 3 and below (assessed by $I s$ values of 2.5), to category 4 and below (assessed by Its) and to categories 3-4 or 3-7 (assessed by $I t$ ). The general deterioration of water quality below the category 3.5 (by CESL1) and category 3 (by CESL2) is also due to destabilization of the landscape structure.

\section{REFERENCES}

AMIRI B., NAKANE K. 2009. Modeling the linkage between river water quality and landscape metrics in the Chugoku district of Japan. Water Resources Management. Vol. 23(5) p. 931-956.

Dosskey M., PhilipPe V., Noel P.G., Craig J.A., Tim P., RiCHARD L. 2010. The role of riparian vegetation in protecting and improving chemical water quality in streams. Journal of the American Water Resources Association (JAWRA). Vol. 46 (2) p. 261-277.

DubNiaK S.S., DubNiaK S.A. 2012. Zakhody shchodo rozvytku baseynovoyi systemy upravlinnya vodnymy resursamy na pryladi baseynu r. Dnipro [Measures for the development of the basin water management system on the example of the Dnieper River Basin] [online]. [Access 18.10.2018]. Available at: ekobereg.com/files/6.doc

FEDONIUK T. 2018. Morphogenetic analysis of the stability of water macrophytes development in the short-term biomonitoring of water ecosystems of the Polesie region of Ukraine. Balanced Nature Using. Vol. 9(1) p. 90-98.

GrodZinSKY M.D., RomanenKo V.D., SHELIAG-SOSONKO Y.R. 2005. Development of the ecological corridor concept for transboundary areas of the Dnipro River Basin. In: Conservation of biological and landscape diversity in the Dnipro (Dnieper) River Basin. Ed. J. Barica. Canadian Association on Water Quality. Monograph Series. No. 6 p. 101-112.

JANKOWSKA-HUFLEJT H. 2006. The function of permanent grasslands in water resources protection. Journal of Water and Land Development. No. 10 p. 55-65.

Klementova E., Heinige V. 1995. Evaluation of ecological stability of agricultural landscape. Melioration and Water Economy. No. 5 p. 24-35.
Lee S., Hwang S., Lee S., Hwang H., Sung H. 2009. Landscape ecological approach to the relationships of land use patterns in watersheds to water quality characteristics. Landscape and Urban Planning. Vol. 92(2) p. 80-89.

MiATKOWSKi Z., SMARZYŃSKA K. 2017. Surface water resources of small agricultural watershed in the Kujawy region, central Poland. Journal of Water and Land Development. No. 33 p. 131-140. DOI 10.1515/jwld-2017-0028.

MiodUSZEWSKI W. 2015. Protection of water quality in the lake situated on the agricultural area. Journal of Water and Land Development. No. 26 p. 65-71. DOI 10.1515/jwld-20150017.

Nash M., Heggem D., Ebert D., Wade T., Hall R. 2009. Multiscale landscape factors influencing stream water quality in the state of Oregon. Environmental Monitoring and Assessment. Vol. 156 (1-4) p. 343-360.

RAMDANi H., LAIFA A. 2017. Physicochemical quality of Wadi Bounamoussa surface waters (Northeast of Algeria). Journal of Water and Land Development. No. 35 p. 183-191. DOI 10.1515/jwld-2017-0083.

Romanchuck L.D., Fedonyuk T.P., Fedonyuk R.G. 2017. Model of influence of landscape vegetation on mass transfer processes. Biosystems Diversity. Vol. 25. No. 3 p. 203-209. DOI $10.15421 / 011731$.

Romanchuk L., FedOnyuk T., PAZych V., Fedonyuk R., Khant G., Petruk A. 2018. Assessment of the stability of aquatic ecosystems development on the basis of indicators of the macrophytes fluctuating asymmetry. Eastern-European Journal of Enterprise Technologies. Vol. 4. No. 11 (94) p. 54-61.

ROMANENKO V., ZHUKINSKIY V. 1998. Metodyka ekolohichnoyi otsinky yakosti poverkhnevykh vod za vidpovidnymy katehoriyamy [Methodology of ecological assessment of surface water quality according to the relevant categories]. Kyiv. Symbol pp. 28.

Shen Z., Hou X., Li W., Aini G., Chen L., Gong Y. 2015. Impact of landscape pattern at multiple spatial scales on water quality: A case study in a typical urbanised watershed in China. Ecological Indicators. Vol. 48 p. 417-427.

SNIZHKO S. 2002. Hidrokhimiya ta radioheokhimiya richok i bolit Zhytomyrs'koyi oblasti [Hydrochemistry and radiogeochemistry of rivers and marshes of Zhytomyr region]. Zhytomyr. Volyn. ISBN 966-690-005-X pp. 264.

Uriarte M., Yackulic C., Lim Y., ARCe-NaZARio J. 2011. Influence of land use on water quality in a tropical landscape: A multi-scale analysis. Landscape Ecology. Vol. 26 (8) p. 1151-1164.

UuemaA E., RoosaAre J., MANDER Ü. 2007. Landscape metrics as indicators of river water quality at catchment scale. Hydrology Research. Vol. 38(2) p. 125-138.

VASENKO O.G. 2005. Ecological status of the transboundary sections of the Dnipro Basin. In: Conservation of biological and landscape diversity in the Dnipro (Dnieper) River Basin. Ed. J. Barica. Canadian Association on Water Quality. Monograph Series. No. 6 p. 1-15.

VASENKo O.G., Rybalova O.V., Kozlovskaya O. 2016. A study of significant factors affecting the quality of water in the Oskil River (Ukraine). Eastern-European Journal of Enterprise Technologies. No. 3/10 p. 48-55.

VasenKo O.H., KorobKova H.V., Rybalova O.V. 2017. Vyznachenia ekolohichykh normatyviv yakosti poverkhnevykh vod $z$ urakhuvaniam prohnoznykh modelei ta rehionalnych osoblyvostei [Determination of environmental norms of surface water quality taking into account forecast models and regional features]. Collquium Journal. No. 2 p. 15-24. 
Zhang D., Li Y., Sun X., Zhang F., Zhu H., LiU Y., Zhu X. 2010. Relationship between landscape pattern and river water quality in Wujingang region, Taihu Lake watershed. Huan Jing Ke Xue. Vol. 31(8) p. 1775-1783.
Zhou T., Wu J., Peng S. 2012. Assessing the effects of landscape pattern on river water quality at multiple sc ales: A case study of the Dongjiang River watershed, China. Ecological Indicators. Vol. 23 p. 166-175.

Tetyana P. FEDONIUK, Roman H. FEDONIUK, Ludmila D. ROMANCHUK, Anatolyy A. PETRUK, Viktor M. PAZYCH

\section{Wpływ struktury krajobrazu na wskaźniki jakości wody}

\section{STRESZCZENIE}

W artykule skupiono się na problemie degradacji struktury i funkcjonowaniu krajobrazu, tj. pilnej potrzebie odniesienia się do strategicznych działań mających zapewnić zintegrowaną ocenę ekologicznej stabilności wód. Określenie wskaźników jakości wody realizowano w blokach według kryteriów: skład mineralny wód, wskaźniki chemiczne i saprobiologiczne oraz stężenie substancji toksycznych i radioaktywnych. W wyniku analiz oznaczono zintegrowany wskaźnik jakości wód i ustalono zależność między jakością wody a wskaźnikami stabilizacji krajobrazu i strukturą elementów biotechnicznych. W artykule określono zależność między pogarszającą się jakością wody a stabilizacją bądź destabilizacją struktur krajobrazu. Badania prowadzono na średnich i dużych ciekach prawobrzeżnej kaskady Dniepru w regionie Polesia, gdzie wyznaczono pasy ziemi i oznaczono dla nich współczynnik stabilności ekologicznej (CESL1) oraz współczynnik krajobrazowych elementów biotechnicznych (CESL2). Przeprowadzono retrospektywną analizę właściwości wód powierzchniowych obszaru badań i ustalono trendy zmian wskaźników zasolenia, wskaźników chemicznych i saprobiologicznych oraz stężenia substancji toksycznych i radioaktywnych. Na podstawie uzyskanych danych wykonano zintegrowaną ocenę jakości wód na obszarze prawobrzeżnej kaskady Dniepru oraz zdefiniowano główne parametry i wpływ skali stabilizacji lub destabilizacji krajobrazu na jakość wód.

Słowa kluczowe: degradacja, jakość wody, kaskada Dniepru, stabilność krajobrazu, wody powierzchniowe 